\title{
"O preparo do médico e a comunicação com familiares sobre a morte"
}

O artigo de Starzewski et al., intitulado "O preparo do médico e a comunicação com familiares sobre a morte", publicado nesta edição, na página 11, é extremamente oportuno por tratar de um tema muito negligenciado, tanto na prática como na formação médica, que é a postura do médico frente à família de um ser que vem a falecer dentro de um hospital-escola - principal palco para a atuação e formação de nossos jovens médicos e estudantes.

Starzewski et al. entrevistaram familiares de pacientes que faleceram quando internados e também os médicos que com eles interagiram logo após a morte de seus parentes, e obtiveram resultados extremamente interessantes. Os autores demonstraram que cerca de um quarto das famílias achou insatisfatória a forma como foram informadas do óbito por não receber suficiente atenção da equipe médica neste difícil momento. Demonstram ainda os autores que apenas uma minoria dos médicos (18,9\%) considerou sua formação acadêmica adequada no tocante a lhes ensinar a enfrentar esta desconfortável situação. A análise da Figura 2 do artigo é especialmente elucidativa. Observamos nesta figura uma grande disparidade na satisfação das famílias avisadas especificamente do óbito seja por telefone (78\%) ou pessoalmente (95\%) em compa- ração àqueles avisados por acaso (0\%). Um fato que prescinde de qualquer análise estatística por refletir uma realidade sobejamente conhecida por todos aqueles que exercem a medicina: temos que nos importar com aqueles que cuidamos e isso inclui também seus familiares. $\mathrm{O}$ ato de especificamente avisar uma família acerca de um óbito de um parente, ainda que por telefone, permite que 0 médico dedique a estas pessoas alguns minutos de seu tempo e demonstre, assim, a sua atenção e compaixão para com elas. É esta a mágica da relação médico-paciente que se estende de forma similar aos seus parentes: dedicação, atenção e compaixão. Ao enxergar a família de um ente falecido sob uma ótica humana, o médico evita a despersonalização da sua prática médica e consegue, desta forma, edificar um verdadeiro relacionamento humano que vislumbra o outro ser na sua totalidade, envolvendo suas emoções e espiritualidade $!$

Um tema que do ponto de vista humanístico é tão palpitante nos faz refletir sobre como devemos então ensinar alunos de medicina e residentes a enfrentar situações de cunho emocional tão intenso como a comunicação da ocorrência de um óbito na família. Existem artigos extremamente didáticos ensinando princípios de como veicular más notícias para pacien- tes ${ }^{2}$ em que se preconiza que 0 médico, em um ambiente adequado e sem pressa, explique de forma clara para o paciente o fato ou condição ruim e permita ainda a este doente, igualmente sem apuro, extravasar suas emoções diante do médico frente à má notícia. A leitura de um artigo, entretanto, não se iguala a vivenciar um professor de medicina fazer o mesmo. Utilizando-se dos anos de experiência e cultivo de sua humanidade junto aos seres que sofrem, o professor fará, melhor do que qualquer artigo, o aluno e o residente experimentarem esta dura situação sob a tutela de quem por ela já passou inúmeras vezes. Experiências como esta, a meu ver, seguramente substituiriam mais uma disciplina no currículo médico já abarrotado de conteúdo. Talvez, o melhor que podemos fazer por nossos alunos e residentes é deixá-los nos ver fazer.

\section{Auro del Giglio}

Referências

1. del Giglio, A. A relação médico paciente sob uma perspectiva dialógica. Revista brasileira de clínica e terapêutica.2002, 27; I: 6-8.

2. Fallowfield L, Jenkins V. Communicating sad, bad, and difficult news in medicine. Lancet. 2004 Jan 24;363(9405):3 I 2-9. PMID: | 4751707. 